\title{
Characterization of Blueberry shock virus, an Emerging Ilarvirus in Cranberry
}

Sara Thomas-Sharma, University of Wisconsin-Madison, Madison, WI; Lindsay Wells-Hansen, Ocean Spray Cranberries Inc., Babcock, WI and University of Wisconsin-Madison; Rae Page, University of Wisconsin-Madison; Victoria Kartanos, Bayer Crop Science, Sacramento, CA and University of Wisconsin-Madison; Erika Saalau-Rojas, UMass Cranberry Station, E. Wareham, MA; Benham. E. L. Lockhart, Department of Plant Pathology, University of Minnesota, St. Paul; and Patricia S. McManus, ${ }^{\dagger}$ University of Wisconsin-Madison

\begin{abstract}
Blueberry shock virus (B1ShV), an Ilarvirus sp. reported only on blueberry, was associated with scarring, disfigurement, and premature reddening of cranberry fruit. BIShV was detected by triple-antibody sandwich enzyme-linked immunosorbent assay and reverse-transcription polymerase chain reaction, and isometric virions of 25 to $28 \mathrm{~nm}$ were observed in cranberry sap. The virus was systemic, although unevenly distributed in plants. The coat protein of BIShV from cranberry shared $90 \%$ identity compared with BIShV accessions from blueberry on GenBank. Phylogenetic analysis of isolates of BIShV from cranberry collected from Wisconsin and Massachusetts did not indicate grouping by state. BlShV was detected in cranberry pollen, and seed transmission of up to $91 \%$

was observed. Artificial inoculation of cranberry flowers by pollination did not cause virus transmission. In some Nicotiana spp., rub inoculation of leaves with homogenized B1ShV-positive cranberry flowers resulted in systemic infection. Cranberry plants recovered from symptoms the year after berry scarring occurred but continued to test positive for BIShV. The virus caused significant reduction in the average number of marketable fruit and average berry weight in symptomatic cranberry plants but recovered plants yielded comparably with healthy plants. Although recovery may limit the immediate economic consequences of BlShV, long-term implications of single- or mixed-virus infection in cranberry is unknown.
\end{abstract}

Cranberry (Vaccinium macrocarpon Aiton, family Ericaceae), a vegetatively propagated perennial crop for which plantings can remain in production for several decades, has had few virus disease problems since it was first cultivated in the late 1800s. Three virusesTobacco streak virus (TSV), Blueberry scorch virus (B1ScV), and Blueberry red ringspot virus-have been described on cranberry but symptoms were generally minor or absent (Jones et al. 2001; Polashock et al. 2009; Wegener et al. 2004). Although TSV was not initially associated with symptoms (Jones et al. 2001), in 2012, TSV was associated with berry scarring in commercial cranberry marshes in Wisconsin (Wells-Hansen et al. 2016). Surveys in Wisconsin in 2013 and 2014 revealed a second virus associated with berry-scarring symptoms, Blueberry shock virus (B1ShV), on 69\% of samples of older cranberry cultivars (Wells-Hansen et al. 2016). Because BlShV has been studied only on highbush blueberry (V. corymbosum L., family Ericaceae) (Bristow and Martin 1999, 2002; MacDonald et al. 1991), there are many knowledge gaps in the biology and economic impact of this recently discovered virus on cranberry.

Wisconsin and Massachusetts together account for $>80 \%$ of the world's cranberry production. Cranberry is the leading fruit crop in Wisconsin, valued at $\$ 146$ million in 2015 , with a harvested area of 8,175 ha $(20,200$ acres) (USDA-NASS 2016). Therefore, the association of BlShV with berry scarring in Wisconsin in 2013 and Massachusetts in 2014 necessitated this study which, excepting preliminary reports (Thomas-Sharma et al. 2015, 2016), is the first investigation of BlShV on cranberry.

BIShV is a typical member of the genus Ilarvirus (family Bromoviridae), with a tripartite genome of positive-sense, single-stranded RNA, and is quasi-isometric in shape (MacDonald et al. 1991). Genomic RNA is directly translated into protein except for coat protein (CP), where a subgenomic RNA is produced from a bicistronic RNA3. The virus was initially detected on blueberry in the Pacific Northwest region of the United States (MacDonald et al. 1991) and has since been detected in other blueberry-growing regions in Canada and the United States, including Michigan, New York,

${ }^{\dagger}$ Corresponding author: P. S. McManus; E-mail: pmcmanus@wisc.edu

Accepted for publication 7 September 2017.

@ 2018 The American Phytopathological Society
Nova Scotia, and Pennsylvania (Martin et al. 2012). BlShV can be detected using nucleic acid (Tzanetakis and Martin 2008) and serological (MacDonald et al. 1991; Sedegui and Osterbauer 2009) detection methods. The virus has a narrow herbaceous host range and causes ringspot-like symptoms on some tobacco varieties artificially inoculated with homogenized blueberry flowers (MacDonald et al. 1991). BlShV has never been found in native vegetation, making the origins of the virus puzzling, and movement of infected planting stock is suspected to introduce disease into new areas (MacDonald et al. 1991).

Like other ilarviruses, B1ShV is pollen-transmitted in blueberry (Bristow and Martin 1999), making the disease particularly challenging to manage. Infection of blueberry occurs specifically during flowering, with the aid of honeybees, and symptoms are noticeable within 1 to 2 years on entire plants or a few branches (Bristow and Martin 1999). In early summer, foliage and flowers of infected blueberry plants appear blighted, eventually dropping off and leaving bare branches. By the end of summer, however, infected plants have a new flush of growth and form reproductive buds for the next year (Bristow and Martin 2002). BlShV-infected blueberry plants become asymptomatic 1 to 3 years after the occurrence of symptoms, a phenomenon referred to as "symptom recovery" or just "recovery" (Bristow and Martin 2002). Thus, although 34 to $90 \%$ yield losses can occur in the year of blighting, recovery limits losses in subsequent years (Bristow and Martin 2002). Recovered plants, however, continue to test positive for the virus and can serve as inoculum sources in the field (Martin et al. 2006).

On cranberry, the symptoms associated with BlShV are similar to those associated with TSV, making visual differentiation of the diseases difficult (Wells-Hansen et al. 2016). Cranberry shoots that arise vertically from prostrate runners, hereafter referred to as "uprights," do not consistently show foliar symptoms, and scarred berries that turn prematurely red are the main symptom of the disease (Fig. 1A). Similar to BlShV on blueberry, TSV infection on cranberry results in symptom recovery (i.e., uprights that have symptomatic fruit in one year bear asymptomatic fruit the following year), and recovered uprights yield comparably with healthy uprights (Wells-Hansen and McManus 2016). If recovery occurs in BlShV-infected cranberry, the immediate economic consequences of the virus may be limited. The objectives of this study were to (i) detect BIShV and determine virus localization in cranberry uprights, (ii) study phylogenetic relationships of BlShV in cranberry, (iii) investigate recovery and the impact of BIShV on yield components of cranberry, and (iv) identify 
inoculum sources and routes for disease transmission. We relate our findings on B1ShV of cranberry to previously described ilarviruses of fruit crops and discuss implications for disease management.

\section{Materials and Methods}

Detection and imaging of BIShV. Serological detection. Plant tissue (maximum of $0.1 \mathrm{~g}$ ), combined with $600 \mu \mathrm{l}$ of general extraction buffer (GEB, provided in a commercial kit; Agdia, Inc., Elkhart, IN), was macerated with 1 or 2 chrome-steel beads in a Mini-BeadBeater (BioSpec Products, Inc., Bartlesville, OK). An aliquot of the sample $(100 \mu \mathrm{l})$ was then tested with a triple-antibody sandwich enzymelinked immunosorbent assay (TAS-ELISA) kit, according to manufacturer instructions. In every 96-well plate, two samples each of controls were included: buffer only, positive control provided in the kit, and leaves from known B1ShV-negative cranberry plants. A test sample was considered positive if the absorbance at $405 \mathrm{~nm}$, measured on a Bio-Rad iMark microplate absorbance reader (Bio-Rad Laboratories, Hercules, CA), was three times the average of the BlShV-negative plant samples.

Reverse-transcription polymerase chain reaction (RT-PCR). Leaves $(0.1 \mathrm{~g})$ from TAS-ELISA-positive plants were harvested from field samples and stored at $-80^{\circ} \mathrm{C}$ until RNA extraction. The leaves were homogenized in liquid nitrogen in a mortar with a pestle, and total RNA was extracted using the Qiagen RNeasy Plant Mini kit, according to manufacturer instructions (Qiagen, Valencia, CA). The RNA was converted to cDNA using iScript Reverse Transcription Supermix for RT-qPCR (Bio-Rad Laboratories). PCR amplification was then carried out using the GoTaq Green Master Mix (Promega Corporation, Madison, WI) in a thermal cycler (Mastercylcer gradient; Eppendorf, Westbury, NY) using primers for RNA3 that yield a 417-bp product (Tzanetakis and Martin 2008). The cycling protocol included a 3-min initial denaturation at $95^{\circ} \mathrm{C}$, followed by 40 cycles of denaturation at $94^{\circ} \mathrm{C}$ for $30 \mathrm{~s}$, annealing at $55^{\circ} \mathrm{C}$ for $30 \mathrm{~s}$, and extension at $72^{\circ} \mathrm{C}$ for $1 \mathrm{~min}$, and a final extension at $72^{\circ} \mathrm{C}$ for $10 \mathrm{~min}$. PCR products were resolved in a $1 \%$ agarose gel in Tris-acetate EDTA that was stained with SYBR Safe (Life Technologies, Grand Island, NY) and viewed on a UV transilluminator.

Transmission electron microscopy. To image virus or virus-like particles, 2- to 5-g leaf samples were ground in liquid nitrogen and extracted with $20 \mathrm{ml}$ of standard extraction buffer, consisting of $500 \mathrm{mM}$ sodium phosphate ( $\mathrm{pH} 7.4), 1 \mathrm{M}$ urea, $5 \%$ (wt/vol) polyvinyl pyrrolidone $(40,000$ molecular weight [MW]), and $0.25 \%$ (vol/vol) 2-mercaptoethanol. The extract was filtered through polyester

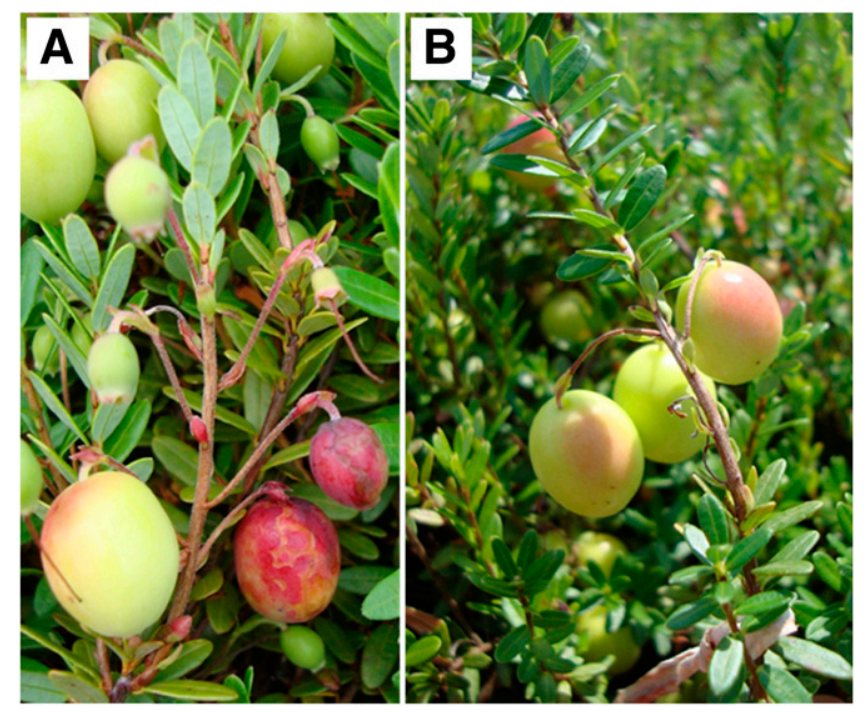

Fig. 1. Symptoms associated with Blueberry shock virus (BIShV). A, Symptomatic, scarred berries that turned prematurely red, observed in cranberry beds in Wisconsin. $\mathbf{B}$, Recovery in BIShV. Symptomatic uprights were tagged in the year when berry scarring occurred. These uprights bore asymptomatic berries for the remainder of the 3 -year study but continued to test positive for the virus. fabric and centrifuged at $20,000 \times g_{\max }$ for $15 \mathrm{~min}$ at $10^{\circ} \mathrm{C}$. The supernatant $(17 \mathrm{ml})$ was layered over $5 \mathrm{ml}$ of $30 \%(\mathrm{wt} / \mathrm{vol})$ sucrose in $100 \mathrm{mM}$ sodium phosphate $(\mathrm{pH} 7.2)$ and centrifuged at $109,000 \times \mathrm{g}_{\max }$ for $2.5 \mathrm{~h}$ at $10^{\circ} \mathrm{C}$. The resulting pellet was resuspended in $100 \mu \mathrm{l}$ of $100 \mathrm{mM}$ sodium phosphate ( $\mathrm{pH} 7.2$ ), extracted with an equal volume of chloroform, and centrifuged for $10 \mathrm{~min}$. The upper aqueous phase constituted the partially purified tissue extract. Carbon-coated transmission electron microscopy (TEM) grids were floated for 2 to $5 \mathrm{~min}$ on $10 \mu \mathrm{l}$ of an aqueous solution of poly-l-lysine $(1,000$ to $5,000 \mathrm{MW}$ ) at $250 \mu \mathrm{g} / \mathrm{ml}$, blotted, and floated for 2 to $5 \mathrm{~min}$ on $10 \mu \mathrm{l}$ of sample consisting of $8 \mu \mathrm{l}$ of partially purified tissue extract and $2 \mu \mathrm{l}$ of $25 \%$ EM-grade glutaraldehyde. For TEM examination, sample grids were then negatively stained by three rinses on $10 \mu \mathrm{l}$ drops of $2 \%(\mathrm{wt} / \mathrm{vol})$ sodium phosphotungstate $(\mathrm{pH} 7.0)$ or uranyl formate.

Localization of BIShV in cranberry and potential sources of inoculum in the field. Cranberry plant samples (cultivar Stevens) were collected throughout the growing seasons of 2014 to 2016 from three commercial cranberry farms in Wisconsin where BlShV had been identified previously. Plant samples were stored at $4^{\circ} \mathrm{C}$ until processing. Various plant parts, including apical buds, flowers, previous- and current-season leaves, asymptomatic berries, symptomatic berries, and roots, were tested for the presence of BlShV by TASELISA. Berries and leaves of wild blueberry ( $V$. angustifolium, $n=35$ ) and leatherleaf (Chamaedaphne calyculata, $n=27$ ), ericaceous weeds in and around cranberry beds on the three farms, were tested for the presence of B1ShV by TAS-ELISA. Cranberry pollen samples ( $n=21$ in 2014 and $n=17$ in 2015) were collected from areas in cranberry beds where the incidence of BIShV was known to be high and tested by TAS-ELISA. An individual sample consisted of pollen pooled from six to eight flowers. Pollen samples were agitated briefly in GEB and then centrifuged to separate pollen grains from the pollen wash. Washing was repeated three to five times until, finally, the pollen was macerated in GEB to obtain pollen extract (Wells-Hansen et al. 2016). All pollen washes and extracts were tested separately.

Phylogenetic studies. Full-length coat protein sequence. RNA3 sequences of BIShV from blueberry (GenBank accessions KF031039.1 and KF030142.1 from the Pacific Northwest region of the United States) were used to design primers to obtain the full-length $\mathrm{CP}$ gene of BlShV from cranberry. The forward and reverse primers were $5^{\prime}$-TATTCCGG CAGTTCCGATAAC-3' and 5'-TCGGGGCATCTAATTCCTTC-3', respectively. RNA extraction, cDNA synthesis, and PCR were conducted as described above on plants previously determined as BIShV-positive by TAS-ELISA. The 993-bp PCR product was cloned into the pGEM-T Easy vector system (Promega Corporation) and the plasmid was used to transform Escherichia coli competent cells. Plasmids were extracted from transformed E. coli using the Wizard Plus Miniprep DNA purification system (Promega Corporation), and the presence of the insert was confirmed by PCR. The plasmid with insert was then sequenced using the forward and reverse primers 5'-CGCCAGGGTTTTCCCAGTCAC GAC-3' and 5'-TCACACAGGAAACAGCTATGAC-3', respectively. Three such insert sequences (deposited to GenBank, accessions numbers KY927862, KY927863, and KY927864) obtained from two different cranberry plants were subjected to BLAST searches on National Center for Biotechnology Information and protein translation tools (ExPASy; Swiss Institute of Bioinformatics, Lausanne, Switzerland). Using the pairwise sequence alignment tool Needle (EMBl-EBI, Cambridgeshire, UK), the nucleotide and amino acid sequences of the $\mathrm{CP}$ open reading frame (ORF) were compared with the Pacific Northwest accessions of BlShV from blueberry.

Diversity of $C P$ in BlShV isolates. RNA was extracted from the leaves of 17 symptomatic uprights collected from three farms each in Wisconsin and Massachusetts. The $\mathrm{CP}$ gene of each isolate was amplified by RT-PCR and sequenced directly. The positive control provided in the TAS-ELISA kit, which originated from blueberry leaf samples from the United States, was cloned and two plasmids with inserts were sequenced and deposited in GenBank (accessions numbers KY927865 and KY927866). The nucleotide sequences of the CP ORF of KY927865 and KY927866 along with the 17 isolates 
from cranberry were included in a multiple sequence alignment with the BlShV accessions from blueberry from the Pacific Northwest. Prunus necrotic ringspot virus (PNRSV, JN416776) was included as the outgroup. The multiple sequence alignment (using ClustalW) and phylogenetic trees were constructed using MEGA, version 6 (Tamura et al. 2013). A maximum-likelihood method was used to construct the phylogenetic trees and maximum-composite-likelihood method was used to compute the distances. A bootstrap test of 1,000 pseudoreplicates was used to assign a confidence value to the branches.

Artificial inoculation of cranberry and herbaceous host plants. Flowers of potted Stevens cranberry plants $(n=14$ pots in 2014 and $n=$ 22 pots in 2015), determined by TAS-ELISA to be BIShV-negative, were inoculated by pollination using pollen collected from BlShVpositive plants in the field. Flowers of two or three plants in each experiment were self-pollinated and served as negative controls. Symptom development on fruit was monitored for approximately 3 months, after which all berries and a sample of leaves from each plant were tested by TAS-ELISA. The plants were overwintered in a cold frame, and the new leaves were tested for BlShV the following year.

Six species or cultivars of herbaceous hosts-Nicotiana benthamiana, N. sylvestris, N. tabacum 'Samsun', N. tabacum 'Havana', $N$. clevelandii, and Helianthus annuus - were maintained in a growth chamber and were inoculated when they were 6 to 8 weeks old. Inoculum was prepared by grinding either B1ShV-positive cranberry leaves or flowers (approximately 20 to 30 each) in $1 \mathrm{ml}$ of buffer (MacDonald et al. 1991; Spiegel and Cohen 1985; Wells-Hansen et al. 2016). Inoculations with macerated leaves and flowers were performed by sprinkling a small amount of diatomaceous earth onto three or four leaves per plant and then rubbing the prepared inoculum onto the leaves with a gloved finger. In each experiment, one or two control plants for each species were mock inoculated with buffer or with macerated leaves of TAS-ELISA-negative cranberry plants. Inoculated plants were observed twice weekly for symptoms that could be indicative of virus infection and tested by TAS-ELISA 2 to 3 weeks after inoculation.

Recovery of cranberry from BIShV symptoms. In summer 2013, 2014, and 2015, 20 to 30 symptomatic cranberry uprights were tagged with twist ties at two (2013 and 2014) or three (2015) farms in Wisconsin. Smaller areas were demarcated as sites within farms. In the following years, we monitored the tagged uprights for symptom development on berries, and collected leaves and berries for testing by TAS-ELISA. Percent return bloom was calculated as the percentage of the originally tagged uprights that produced flowers in successive years (Wells-Hansen and McManus 2016).

Effect of BIShV on yield components. In early August 2015, 100 to 150 uprights with symptomatic berries were tagged using twist ties at three farms in Wisconsin. In September 2015 (2 weeks before commercial harvest), about 70 to 85 of these symptomatic uprights along with about 300 to 500 uprights with asymptomatic berries were collected from each site. On each asymptomatic upright, currentseason leaves, previous-season leaves, and one asymptomatic berry were tested by TAS-ELISA. An upright was considered infected if at least one of the plant parts tested positive for BlShV. These results were used to classify asymptomatic uprights as either healthy
(ELISA-negative) or recovered (ELISA-positive). Individual uprights were evaluated by counting and weighing the total marketable berries, and counting the number of aborted berries, small berries, and pedicels (as a late-season indicator of flowering). The data were used to calculate the response variables: fruit set, marketable berry number, and individual berry weight. Fruit set was calculated as the sum of marketable berries and small berries divided by the number of pedicels, and expressed as a percentage. Individual berry weight was calculated by dividing the weight of marketable berries by the number of marketable berries. Analysis of variance was conducted on fruit set (natural log transformed after converting zeros to 0.0001) and individual berry weight whereas for marketable fruit number, a Quasipoisson generalized linear model was fitted with pedicel number as the offset value. For all response variables, upright status (i.e., healthy, recovered, or symptomatic) served as the explanatory variable and analysis was carried out separately for each farm. When upright status had a statistically significant result $(P<0.05)$, Tukey's honestly significant difference test was used for mean separation. All statistical analyses were conducted in $\mathrm{R}$ version 3.3.2 (R Core Team 2015).

Transmission of BIShV through vegetative and sexual progeny. In January 2016, dormant cranberry vine cuttings were collected from the field. Leaves of individual uprights were tested by TAS-ELISA and the subtending runners were accordingly classified as healthy or infected. Vine cuttings ( 6 to $8 \mathrm{~cm}$ ) were planted and maintained in the greenhouse. New leaves from the cuttings were tested for BlShV by TAS-ELISA 1 to 2 months later.

Seed were extracted from surface-disinfested ripe berries (WellsHansen et al. 2016) of uprights classified as healthy, symptomatic, or recovered collected from each of the aforementioned three farms in Wisconsin. For germination, seed were treated overnight in gibberellic acid at 2,000 ppm, washed three times in sterile water, and pressed gently into water agar in $36-\mathrm{cm}^{2}$ tissue culture boxes (Magenta, Chicago). After incubation in a south-facing window of the laboratory, seedlings emerged in 3 to 4 months. Individual seed or seedlings were crushed in $300 \mu \mathrm{l}$ of GEB and tested by TAS-ELISA. Virus incidence in seed and seedlings that grew from seed in each of the upright categories was calculated separately for each farm.

\section{Results}

Detection and imaging of BIShV. BIShV was detected in cranberry leaves by complementary serological and nucleic acid-based detection methods. Commercial TAS-ELISA kits successfully detected BlShV and were used for routine detection throughout this study. RT-PCR primers (designed for BlShV in blueberry) gave a product of expected size and sequence from TAS-ELISA-positive BlShV samples. Transmission electron micrographs showed the presence of isometric particles of 25 to $28 \mathrm{~nm}$, consistent with size descriptions of BlShV (MacDonald et al. 1991).

Localization of BIShV in cranberry and potential sources of inoculum in the field. BlShV was detected in different parts of cranberry plants, including apical buds, leaves (both current- and previous-season), flowers, and berries (symptomatic and asymptomatic) (Table 1). In infected cranberry uprights (i.e., uprights in which at least one plant part tested positive), detection of B1ShV in all plant parts was often $<100 \%$ (Table 1). BlShV was detected in $62 \%(n=34)$ of root samples taken

Table 1. Detection of Blueberry shock virus (BIShV) by triple-antibody sandwich enzyme-linked immunosorbent assay in different parts of infected cranberry uprights

\begin{tabular}{lccccccc}
\hline & & \multicolumn{6}{c}{ Percent incidence of BIShV in plant part $^{\mathbf{a}}$} \\
\cline { 3 - 7 } $\begin{array}{l}\text { Time of } \\
\text { testing }\end{array}$ & $\begin{array}{c}\text { Presence of } \\
\text { symptoms }\end{array}$ & $\begin{array}{c}\text { Apical } \\
\text { buds }\end{array}$ & Flowers & $\begin{array}{c}\text { Previous-season } \\
\text { leaves }\end{array}$ & $\begin{array}{c}\text { Current-season } \\
\text { leaves }\end{array}$ & $\begin{array}{c}\text { Asymptomatic } \\
\text { berry }\end{array}$ & $\begin{array}{c}\text { Symptomatic } \\
\text { berry }\end{array}$ \\
\hline Before bloom & $\ldots$ & $70(44)$ & $\ldots$ & $82(67)$ & $100(21)$ & $\ldots$ & $\ldots$ \\
During bloom & $\ldots$ & $\ldots$ & $91(64)$ & $87(63)$ & $84(62)$ & $\ldots$ & $\ldots$ \\
After fruit set & Asymptomatic & $\ldots$ & $\ldots$ & $91(226)$ & $89(312)$ & $28(337)$ & $\ldots$ \\
& Symptomatic & $\ldots$ & $\ldots$ & $82(239)$ & $61(243)$ & $28(25)$ & $94(117)$ \\
\hline
\end{tabular}

\footnotetext{
${ }^{a}$ An upright was considered infected if at least one plant part tested positive. Numbers in parentheses indicate sample size.

${ }^{\mathrm{b}}$ Berry scarring is the only symptom of the disease.
} 
from runners before bloom and after fruit set. BlShV was not detected in either wild blueberry or leatherleaf. Incidence of BIShV in pollen extracts was 76 and 53\% in 2014 and 2015, respectively. Pollen washes were consistently negative for the virus.

Phylogenetic studies. The cranberry and blueberry isolates shared 89.9 to 90.8 and 93.4 to $93.9 \%$ amino acid identity and similarity, respectively, and 89.7 to $90.1 \%$ nucleotide similarity. The length of the CP ORF was 677 to 687 among the 17 isolates of BIShV from cranberry. The cranberry isolates grouped into a single clade and did not group based on geography (Fig. 2).

Artificial inoculation of cranberry plants and other herbaceous hosts. None of the healthy cranberry plants inoculated by pollination with BlShV-positive pollen developed symptomatic berries or tested positive for BlShV. None of the herbaceous plants that

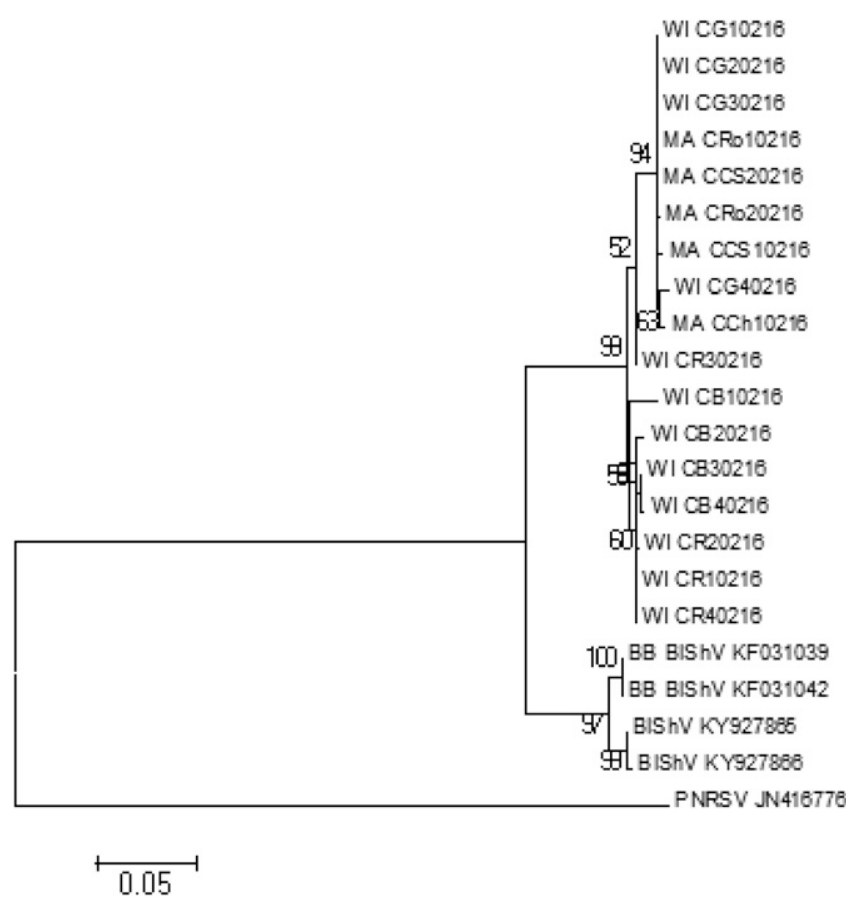

Fig. 2. Inferred phylogenetic tree of 17 Blueberry shock virus (BIShV) isolates on cranberry in relation to other members of family Bromoviridae sequenced separately or available in GenBank. Isolates in cranberry begin with "C" and were from Wisconsin (preceded by WI) or Massachusetts (preceded by MA). Isolates BIShV_KY927865 and BIShV_KY927866 were obtained by cloning and sequencing the positive control supplied in the triple-antibody sandwich enzyme-linked immunosorbent assay kit (originally isolated from blueberry leaves from the United States). Published sequences from GenBank were included as representative sequences for BIShV on blueberry (BB BIShV: KF031042.1 and KF031039.1) and Prunus necrotic ringspot virus (PNRSV: JN416778), the latter serving as the outgroup. Numbers at the branches are bootstrap values $(1,000$ pseudoreplicates). were inoculated with macerated cranberry leaves tested positive for BlShV or developed symptoms. Three species of Nicotiana inoculated with macerated cranberry flowers developed systemic infection by BlShV (Table 2). Two N. benthamiana plants tested positive for BlShV but were asymptomatic, while all other infected plants developed etching symptoms (Fig. 3).

Recovery from BIShV symptoms. Symptomatic uprights that were tagged in one season produced asymptomatic fruit (when they produced fruit) the following years for the remainder of the study (Fig. 1B) but their leaves continued to test positive for BIShV. The return bloom on these uprights varied by year and site and ranged from 5 to 79 and 11 to $68 \%$ in the first and second years after symptom observation, respectively (Table 3 ).

Effect of BIShV on yield components. Yield components were variable among farms (Fig. 4). The average fruit set was comparable across upright categories, except at farm 2, where symptomatic uprights had significantly lower fruit set (Fig. 4B). The average marketable berry numbers and the average berry weight were significantly lower in symptomatic uprights at all three farms. None of the farms showed a statistically significant difference between recovered and healthy uprights with regard to the average marketable berry number and the average berry weight.

Natural transmission of BIShV through vegetative and sexual progeny. A high incidence of BIShV (97\% of $n=194)$ was observed in new leaves of plants propagated from vine cuttings of infected cranberry. A low incidence of BIShV (4.6\% of $n=194)$ was observed in plants propagated from vine cuttings classified as healthy (i.e., leaves from the uprights themselves were BlShV-negative or the runner subtended only negative uprights). BlShV incidence was high in both seed and seedlings from healthy, symptomatic, and recovered uprights (Table 4). Seed originating from uprights that were classified as healthy had 1 to $4 \%$ incidence of BIShV, whereas seedlings originating from these same uprights had 46 to $72 \%$ incidence.

\section{Discussion}

We detected BIShV in cranberry plants by TAS-ELISA and RTPCR and observed isometric virions in cranberry sap by TEM. Originally reported on cranberry in association with fruit-scarring symptoms in Wisconsin (Wells-Hansen et al. 2016), BlShV has since been identified on cranberry in British Columbia, Massachusetts, New Jersey, and Oregon (Polashock 2017). The occurrence of B1ShV in major cranberry production regions across North America underscores the importance of the current study, which fills several knowledge gaps concerning the biology and epidemiology of this emerging pathogen.

Using TAS-ELISA, we detected BIShV in all cranberry plant parts, thereby confirming the systemic nature of the virus. The incidence of BlShV in parts of infected cranberry uprights was often $<100 \%$, indicating uneven virus distribution. Such uneven distribution of viruses in planta has been observed in many pathosystems and can affect virus detection and transmission (Kominek et al. 2009; Kritzman et al. 2001). In our work, uneven BlShV distribution

Table 2. Artificial inoculation of herbaceous plants to determine Blueberry shock virus (B1ShV) host range

\begin{tabular}{|c|c|c|c|}
\hline \multirow[b]{3}{*}{ Plant species inoculated } & \multicolumn{3}{|c|}{$\begin{array}{c}\begin{array}{c}\text { Number of plants testing positive for BIShV following inoculation with macerated leaves or flowers in two } \\
\text { buffers (total number inoculated) }\end{array}\end{array}$} \\
\hline & \multirow{2}{*}{$\frac{\text { Macerated leaves }}{\text { Potassium phosphate }}$} & \multicolumn{2}{|c|}{ Macerated flowers } \\
\hline & & Potassium phosphate & $\overline{\text { Sodium phosphate }}$ \\
\hline Nicotiana benthamiana & $0(14)$ & $4(5)$ & $1(4)$ \\
\hline N. sylvestris & $0(6)$ & $0(2)$ & $0(2)$ \\
\hline N. tabacum 'Samsun' & $0(8)$ & $2(4)$ & $1(4)$ \\
\hline N. tabacum 'Havana' & $0(14)$ & $0(2)$ & $0(4)$ \\
\hline N. clevelandii & $0(7)$ & $0(3)$ & $1(4)$ \\
\hline Helianthus аппииs & $0(6)$ & $0(5)$ & $0(5)$ \\
\hline
\end{tabular}

${ }^{a}$ Leaves of BlShV-positive cranberry plants maintained in the greenhouse or flowers collected from infected plants in the field were macerated in buffer and used to rub inoculate leaves of herbaceous hosts. One to three control plants of each species or cultivar that were mock inoculated with water did not develop symptoms and tested negative for BlShV by triple-antibody sandwich enzyme-linked immunosorbent assay. Data are combined over two trials and the number in parentheses is combined sample size. Not every species or cultivar was included in both trials. 
resulted in false negatives, because we sometimes detected the virus upon retesting parts of cranberry uprights that were previously classified as healthy (based on a negative TAS-ELISA result). In cranberry infected with TSV, systematic sampling through the growing season revealed that the distribution of TSV was relatively uniform in recovered uprights but uneven in symptomatic uprights (WellsHansen and McManus 2016). Thus, when screening for viruses in cranberry, testing both leaves and berries is advised to avoid falsenegative results.

B1ShV on cranberry shared only $90 \%$ CP identity with blueberry accessions in GenBank. Phylogenetic trees indicated that B1ShV from blueberry and BIShV from cranberry formed distinct clades by host. Taken together, these observations suggest that BIShV on cranberry is distinct from BlShV on blueberry. There are no specified levels of sequence similarity to differentiate strains and species of ilarviruses (Roossinck et al. 2005). Because extant field isolates of BlShV from blueberry were not included in this study, more sampling is necessary to conclusively establish host-based strain differences and the evolution of BIShV on Vaccinium hosts.

B1ShV isolates from cranberry did not group based on their geographic origin, similar to what was observed for TSV on cranberry (Wells-Hansen et al. 2016). Among virus isolates collected from Wisconsin, the pairwise identity of $\mathrm{CP}$ nucleotide sequences was 90.9 to $99.9 \%$ for TSV and 96.1 to $100 \%$ in B1ShV, indicating less diversity in BlShV. The similarity of BlShV isolates from Wisconsin and Massachusetts is possibly because of the narrow host range of the virus (Table 2) (MacDonald et al. 1991) and suggests a relatively recent introduction of BlShV into cranberry. However, the origins of $\mathrm{BlShV}$ in cranberry remain elusive, because the ericaceous weeds (wild blueberry and leatherleaf) that were abundant in and near infected beds in Wisconsin tested negative for the virus.

We detected BlShV in extracts of crushed cranberry pollen but not in pollen washes. This internalization of the virus differs from B1ShV on blueberry (Bristow and Martin 1999), TSV on cranberry (WellsHansen et al. 2016), and PNRSV in apricot (Amari et al. 2007), where the viruses were detected in both washes and extracts of pollen. The presence of BlShV in cranberry pollen grains prompted our studies on the role of pollen in horizontal and vertical transmission of the virus.

Horizontal (plant-to-plant) transmission of pollen-borne viral diseases can occur when infected pollen transmits disease to healthy maternal tissue during fertilization (Card et al. 2007). In Torenia plants inoculated with raspberry pollen infected with Raspberry bushy dwarf virus (genus Idaeovirus), the virus was found to infect the stigma and style during pollen tube elongation (Isogai et al. 2014).

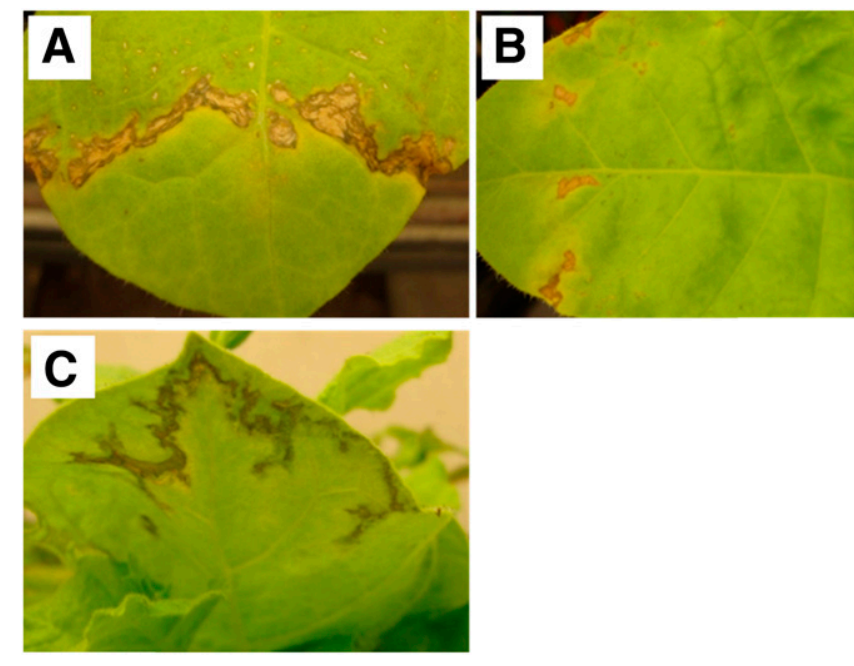

Fig. 3. Symptoms that developed 2 to 3 weeks after mechanical transmission of Blueberry shock virus to A and B, Nicotiana tabacum 'Samsun' and C, N. benthamiana.
In BlShV on blueberry, the presence of honeybees during bloom resulted in transmission of the virus to healthy trap plants, implying that honeybees are the vectors of infected pollen (Bristow and Martin 1999). However, when we hand-pollinated healthy cranberry plants with B1ShV-infected pollen, we failed to reproduce berry-scarring symptoms, and neither fruit nor leaves of the pollinated plants tested positive for B1ShV. The unsuccessful transmission of BlShV to cranberry plants probably cannot be attributed to low infectivity of the virus, because when flowers from BlShV-infected fields were used as inoculum, $N$. benthamiana became systemically infected and developed symptoms. Lack of transmission by pollination might have been because the inoculated flowers were not emasculated, allowing them to self-pollinate with healthy pollen. Alternatively, pollination might not be a significant mode of BlShV horizontal transmission in cranberry.

Vertical transmission of plant viruses occurs when the embryo within a seed is infected during fertilization (i.e., because of infection in pollen or ovule) or during embryo development, postfertilization (Card et al. 2007). A very low rate of BlShV transmission (1.2\%) was observed in blueberry seed (Bristow and Martin 1999), and no transmission of TSV was observed in cranberry seed (WellsHansen et al. 2016). By contrast, we observed vertical transmission of BlShV at rates up to $91 \%$ in cranberry seed. Cranberry seed can germinate in the field and, thus, if animals or humans move infected cranberry fruit, the establishment of infected seedlings could introduce the disease to new areas. Although the reasons for variability of BlShV incidence in ungerminated seed are unclear, the health of the seedlings is independent of the health of the mother plant (healthy, recovered, or symptomatic). The availability of more tissue in seedlings and virus replication in such tissues possibly reduced the occurrence of false negatives and gave a true representation of seed transmission.

Commercially, cranberry is vegetatively propagated from dormant or rooted vine cuttings. In our studies, 97\% of cuttings taken from infected runners tested positive for B1ShV. Because there are no industry-wide certification programs established for cranberry propagation material, the unrestricted movement of infected planting material is potentially an important source of inoculum. Thus, ensuring that the vines used for propagation are not sourced from infected beds can delay disease introduction, but given the pollen-borne nature of BlShV and high seed transmission rate, new introductions cannot be eliminated. Similarly, bed management practices such as killing flowers of newly established beds by withholding frost protection or reflooding bearing beds after harvest to remove remaining berries that might contain infected seed can also reduce inoculum and delay disease development.

$\mathrm{B} 1 \mathrm{ShV}$-infected symptomatic cranberry uprights recovered from symptoms, similar to the recovery phenomenon described for TSV in cranberry (Wells-Hansen and McManus 2016) and BlShV in blueberry (Bristow and Martin 2002). Recovered cranberry uprights

Table 3. Percent return bloom on symptomatic uprights 1 or 2 years after observation of initial symptoms associated with Blueberry shock virus ${ }^{\mathrm{a}}$

\begin{tabular}{lccc}
\hline Year of symptoms & Site $^{\mathbf{b}}$ & $\begin{array}{c}\text { First year } \\
\text { after symptoms }\end{array}$ & $\begin{array}{c}\text { Second year } \\
\text { after symptoms }\end{array}$ \\
\hline 2013 & 1 & $5(22)$ & $68(19)$ \\
2014 & 2 & $17(17)$ & $47(15)$ \\
& 3 & $10(20)$ & $57(7)$ \\
2015 & 4 & $29(21)$ & $36(11)$ \\
& 5 & $13(15)$ & $11(9)$ \\
& 6 & $79(28)$ & $\ldots$ \\
& 7 & $58(19)$ & $\ldots$ \\
\hline
\end{tabular}

${ }^{\text {a }}$ Return bloom was calculated as the percentage of the originally tagged uprights that produced flowers in successive years. The number in parentheses indicates sample size.

${ }^{\mathrm{b}}$ Sites were smaller areas demarcated each year within the three commercial cranberry farms in Wisconsin. 
continued to bloom at rates considered normal given the variability in return bloom reported previously for cranberry (DeVetter et al. 2013; Wells-Hansen et al. 2016). Studies on the mechanism of recovery in annual plants has indicated that transcriptome reprogramming, including RNA silencing, is responsible for recovery from virus infection (Bengyella et al. 2015). Similar mechanisms may be at play in cranberry. We have isolated $\mathrm{BlShV}$-specific small interfering RNA (siRNA; data not shown) in recovered cranberry leaves, suggesting that RNA silencing was triggered.

Because B1ShV is a new disease problem for the cranberry industry, there was a need to determine impact of the virus on yield. Given the inherent variability in bed-wide cranberry yield (Pozdnyakova et al. 2005), we measured yield components on individual cranberry uprights, as conducted previously (Roper et al. 1993; Wells-Hansen and McManus 2016). For this, we classified uprights as recovered, healthy, and symptomatic based on fruit appearance and TAS-ELISA tests. Because the time between infection and symptom expression is not known, it is possible that uprights classified as recovered included latently infected uprights that had not shown symptoms previously. Despite this caveat, our results indicate that a reduction in the number of marketable berries on symptomatic uprights and average weight of symptomatic berries are the major detriments to yield. Recovered uprights, however, were comparable with healthy uprights for all yield components measured. Thus, similar to observations of cranberry yield recovery from TSV infection (Wells-Hansen and McManus 2016) and blueberry yield recovery from BIShV infection (Bristow and Martin 2002), recovery also limits the immediate economic consequences of BlShV on cranberry.

In this study, we have documented substantial similarities between BIShV and TSV on cranberry with regard to symptomatology, virus distribution within plants, symptom recovery, and impact on yield. The apparent simultaneous emergence of the two ilarviruses as disease concerns in cranberry raises questions about the future importance of virus diseases in this long-lived perennial crop. In the current study (unpublished data) and previous work (Wells-Hansen et al. 2016), we did not detect TSV and B1ShV on the same cranberry upright, and siRNA sequencing and assembly did not reveal sequences of other viruses (unpublished data). However, in some blueberry varieties, dual infection by BlShV and BlScV causes a characteristic red leaf spot symptom (Martin 2017). If mixed virus infections involving BlShV in cranberry were to evolve, interactions between viruses might result in greater economic impact than losses incurred by single infections.

Table 4. Incidence of Blueberry shock virus (BIShV) in seed and seedlings of cranberry

\begin{tabular}{lcccc}
\hline $\begin{array}{l}\text { Plant } \\
\text { material } \\
\text { tested }\end{array}$ & $\begin{array}{c}\text { Farm } \\
\text { number }\end{array}$ & \multicolumn{2}{c}{$\begin{array}{c}\text { Percent incidence of BIShV in seeds or } \\
\text { seedlings from different upright categories }\end{array}$} \\
\cline { 2 - 5 } & Healthy & Recovered & Symptomatic \\
\hline Seed & 1 & $1(75)$ & $75(75)$ & $12(73)$ \\
& 2 & $4(57)$ & $26(57)$ & $29(58)$ \\
& 3 & $4(100)$ & $67(100)$ & $11(100)$ \\
Seedlings & 1 & $46(56)$ & $54(41)$ & $56(41)$ \\
& 2 & $64(39)$ & $79(38)$ & $86(43)$ \\
& 3 & $72(32)$ & $85(33)$ & $91(44)$ \\
\hline
\end{tabular}

a Seeds were extracted from cranberry uprights that were classified as healthy (if asymptomatic and BIShV-negative), recovered (if asymptomatic and BlShV-positive), and symptomatic. The number in parentheses is sample size.
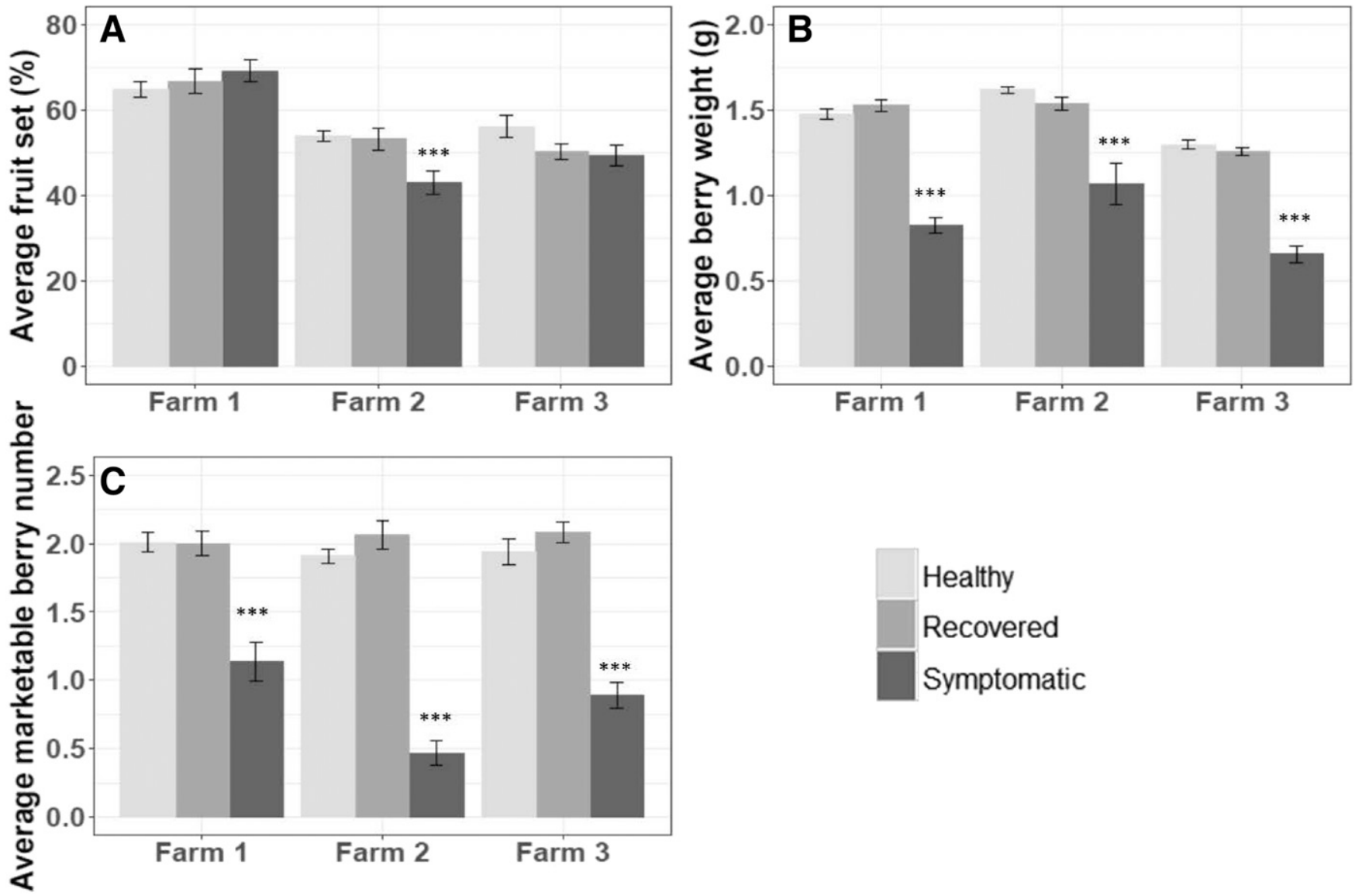

Farm 1

Farm 2

Farm 3

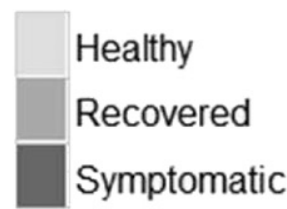

Fig. 4. Effect of Blueberry shock virus (BIShV) on yield components of cranberry from three farms in Wisconsin. Cranberry uprights were classified as healthy (if asymptomatic and BIShV-negative by triple-antibody sandwich enzyme-linked immunosorbent assay [TAS-ELISA]), recovered (if asymptomatic and BIShV-positive by TAS-ELISA), and symptomatic. Yield components calculated for each of the upright categories were A, average fruit set ([number of marketable fruit + number of small fruit/number of pedicels] $\times 100) ; \mathbf{B}$, average berry weight (weight of total marketable berries/number of marketable berries); and $\mathbf{C}$, average marketable berry number per upright. Bars represent standard errors. Statistical significance is represented by ${ }^{* * *}$ above the bars $(P<0.001)$. 
The findings reported here will provide a basis for ongoing efforts to manage BIShV and monitor its effect on cranberry health.

\section{Acknowledgments}

We thank anonymous reviewers for their helpful comments, cranberry growers who gave us access to their field sites for this study, T. German and R. Dasgupta for helpful discussions, M. Hughan for aid in sample collection and analysis, and M. Kamenetsky for help with statistical analysis. This research was funded by the United States Department of Agriculture Specialty Crop Block Grant Program (project number 14-015), Wisconsin Cranberry Board, Inc., Ocean Spray Cranberries, Inc., and Cranberry Institute.

\section{Literature Cited}

Amari, K., Burgos, L., Pallas, V., and Sanchez-Pina, M. A. 2007. Prunus necrotic ringspot virus early invasion and its effects on apricot pollen grain performance. Phytopathology 97:892-899.

Bengyella, L., Waikhom, S. D., Allie, F., and Rey, C. 2015. Virus tolerance and recovery from viral induced-symptoms in plants are associated with transcriptome reprograming. Plant Mol. Biol. 89:243-252.

Bristow, P. R., and Martin, R. R. 1999. Transmission and the role of honeybees in field spread of blueberry shock ilarvirus, a pollen-borne virus of highbush blueberry. Phytopathology 89:124-130.

Bristow, P. R., and Martin, R. R. 2002. Recovery of plants infected with blueberry shock ilarvirus (B1ShV). Acta Hortic. 574:85-89.

Card, S., Pearson, M., and Clover, G. 2007. Plant pathogens transmitted by pollen. Australas. Plant Pathol. 36:455-461.

DeVetter, L. W., Harbut, R., and Colquhoun, J. 2013. Bud development, return bloom, and external bud appearance differ among cranberry cultivars. J. Am. Soc. Hortic. Sci. 138:338-343.

Isogai, M., Yoshida, T., Nakanowatari, C., and Yoshikawa, N. 2014. Penetration of pollen tubes with accumulated Raspberry bushy dwarf virus into stigmas is involved in initial infection of maternal tissue and horizontal transmission. Virology 452:247-253.

Jones, A. T., McGavin, W. J., and Dolan, A. 2001. Detection of Tobacco streak virus isolates in North American cranberry (Vaccinium macrocarpon Ait.). Online publication. Plant Health Prog. doi:10.1094/PHP-2001-0717-01-RS

Kominek, P., Glasa, M., and Kominkova, M. 2009. Analysis of multiple virusinfected grapevine plant reveals persistence but uneven virus distribution. Acta Virol. 53:281-285.

Kritzman, A., Lampel, M., Raccah, B., and Gera, A. 2001. Distribution and transmission of Iris yellow spot virus. Plant Dis. 85:838-842.

MacDonald, S. G., Martin, R. R., and Bristow, P. R. 1991. Characterization of an ilarvirus associated with a necrotic shock reaction in blueberry. Phytopathology 81:210-214.

Martin, R. R. 2017. Shock, diseases caused by viruses, blueberries. Pages 72-73 in: Compendium of Blueberry, Cranberry, and Lingonberry Diseases and Pests. J. J. Polashock, F. L. Caruso, A. L. Averill, and A. C. Schilder, eds. The American Phytopathological Society, St. Paul, MN.

Martin, R. R., Bristow, P. R., and Wegener, L. A. 2006. Scorch and shock: Emerging virus diseases of highbush blueberry and other Vaccinium species.
Pages 463-467 in: Proc. 8th Int. Symp. Vaccinium Culture. L. L. DaFonseca and F. R. Munoz, eds.

Martin, R. R., Polashock, J. J., and Tzanetakis, I. E. 2012. New and emerging viruses of blueberry and cranberry. Viruses 4:2831-2852.

Polashock, J. J. 2017. Shock, Diseases caused by viruses, cranberries. Pages 120-122 in: Compendium of Blueberry, Cranberry, and Lingonberry Diseases and Pests. J. J. Polashock, F. L. Caruso, A. L. Averill, and A. C. Schilder, eds. The American Phytopathological Society, St. Paul, MN.

Polashock, J. J., Ehlenfeldt, M. K., and Crouch, J. A. 2009. Molecular detection and discrimination of Blueberry red ringspot virus strains causing disease in cultivated blueberry and cranberry. Plant Dis. 93:727-733.

Pozdnyakova, L., Gimenez, D., and Oudemans, P. V. 2005. Spatial analysis of cranberry yield at three scales. Agron. J. 97:49-57.

R Core Team. 2015. R: A Language and Environment for Statistical Computing. R Foundation for Statistical Computing, Vienna, Austria.

Roossinck, M. J., Bujarski, J., Ding, S. W., Hajimorad, R., Hanada, K., Scott, S. and Tousigant, M. 2005. Family Bromoviridae. Pages 1049-1058 in: Virus Taxonomy: VIIIth Report of the International Committee on Taxonomy of Viruses. C. M. Fauquet, M. A. Mayo, J. Maniloff, U. Desselberger, and L. A. Ball, eds. Elsevier Inc., San Diego, CA.

Roper, T. R., Patten, K. D., Demoranville, C. J., Davenport, J. R., Strik, B. C., and Poole, A. P. 1993. Fruiting of cranberry uprights reduces fruiting the following year. HortScience 28:228.

Sedegui, M., and Osterbauer, N. 2009. Evaluation of a high-throughput protocol for detecting Blueberry shock virus in Vaccinium using ELISA. Online publication. Plant Health Prog. doi: 10.1094/PHP-2001-0717-01-RS

Spiegel, S., and Cohen, J. 1985. Occurrence of tobacco streak virus in strawberries in Israel. Plant Dis. 69:448-449.

Tamura, K., Stecher, G., Peterson, D., Filipski, A., and Kumar, S. 2013. MEGA6: Molecular Evolutionary Genetics Analysis version 6.0. Mol. Biol. Evol. 30: 2725-2729.

Thomas-Sharma, S., Wells, L., Kartanos, V., Saalau-Rojas, E., and McManus, P. 2015. Preliminary insights into the epidemiology of Blueberry shock virus in cranberry. (Abstr.) Phytopathology 105:S4.137.

Thomas-Sharma, S., Wells-Hansen, L., Page, R., Kartanow, V., Saalau-Rojas, E., and McManus, P. 2016. Epidemiological insights into an emerging virus disease: Blueberry shock virus on cranberry. (Abstr.) Phytopathology 106:S4.2.

Tzanetakis, I. E., and Martin, R. R. 2008. A new method for extraction of doublestranded RNA from plants. J. Virol. Methods 149:167-170.

USDA-NASS. 2016. Noncitrus Fruits and Nuts, 2015 Summary. United States Department of Agriculture National Agricultural Statistics Service (USDA-NASS), Washington, D.C.

Wegener, L. A., Punja, Z. K., and Martin, R. R. 2004. First report of Blueberry scorch virus in cranberry in Canada and the United States. Plant Dis. 88:427.

Wells-Hansen, L. D., and McManus, P. 2016. Recovery of cranberry plants infected with Tobacco streak virus and incidence and distribution of TSV in the field. Plant Dis. 100:2257-2265.

Wells-Hansen, L. D., Polashock, J. J., Vorsa, N., Lockhart, B. E. L., and McManus, P. S. 2016. Identification of Tobacco streak virus in cranberry and the association of TSV with berry scarring. Plant Dis. 100:696-703. 